\title{
Occurrence of drug resistant bacteria in household waste samples
}

\author{
Aklima Akter, Sadia Ahmed, Tamanna Islam and Saurab Kishore Munshi* \\ Department of Microbiology, Stamford University Bangladesh, 51, Siddeswari Road, Dhaka-1217, Bangladesh
}

Received 02 June 2019/Accepted 22 August 2019

\begin{abstract}
Current study was carried out to investigate the presence of drug resistant bacterial isolates in the biodegradable household waste samples. In this respect, a total of six domestic waste samples including three kitchen waste samples and one sample each of home dust, dustbin waste and liquid waste were collected. Samples were analyzed for quantification of bacterial load and along with their drug susceptibility pattern. Huge array of total viable bacteria was present in all the samples (in average of $10^{8} \mathrm{cfu} / \mathrm{g}$ or $\mathrm{ml}$ ). Among the specific bacteria, Bacillus spp. was predominant and Vibrio spp. was found in almost all samples except liquid waste. Presence of Staphylococcus spp., E. coli, Klebsiella spp., Pseudomonas spp., Salmonella spp. and fecal coliform were evident in some samples. All isolates were found to be multidrug resistant. Notably, $100 \%$ resistance was documented against cefuroxime and amoxicillin. All the isolates showed sensitivity against meropenem, amikacin and ceftriaxone. Presence of drug resistant bacteria in household waste samples in present study critically raises the requirement for proper management and disposal of the accumulated domestic wastes by the municipal and government authorities.
\end{abstract}

Keywords: Household waste, Municipal waste, Kitchen waste, Home dust, Microbiological analysis, Drug resistance.

\section{INTRODUCTION}

For environmental sustainability, waste generation and its control have played an important role. The quantity of municipal waste generated increases at an alarming rate with population doubling and changing lifestyle patterns of the inhabitants. Any type of wastes produced from a domestic source is called domestic or household waste, which represents more than two-third of the solid waste stream of municipal area $(1,2)$. These are in either solid or semisolid form and usually devoid of hazardous industrial wastes. In general, household waste can be classified into five broad categories; (a) Biodegradable waste: food and cooking waste, green waste (vegetables, flowers, fruits, leaves), paper (can also be recycled), (b) Recyclable material: paper, cans, bottles, tubes, metals, other materials, etc., (c) Inert waste: waste from construction and demolition, dirt, rocks, debris, (d) Composite waste: waste from clothing, tetra packs, plastics such as toys, and (e) Domestic or household hazardous waste and toxic waste: medication, paints, e-waste, light bulbs, chemicals, fluorescent tubes, fertilizer and pesticide containers, spray cans, shoe polish etc. (3).

Household wastes, especially kitchen wastes are rich in nutrients, or eutrophic, those contain high level of carbohydrates, lipids, proteins and other organic molecules that can sustain abundant microbial populations (4). In the household waste environment, there is a syntrophic and nutritionally mutualistic relationship occurs among the microorganisms establishing an anaerobic food web. Hydrolytic enzymes split complex molecules into monomers that fermentative bacteria can use. Fermentation products further reduces to methane by methanogens (5). Pseudomonas aeruginosa also produces a biosurfacant named rhamnolipid that may improve the bioavailability of nutrients for other bacteria in the kitchen and other household wastes (6). Competitive and cooperative interactions among bacterial populations in the nutrient rich household waste environment help them to thrive. Household dust, on the other hand is a complex mixture of various substances of $0.001-1 \mathrm{~mm}$ in diameter, such as fibers, dander, hair, paint chips, combustion products, sand, dead insects, pollen, algae, fungal spores and bacteria (7). Several studies were carried out for investigating microbial presence in household dust (7-9).

Improper dumping of untreated waste in rivers, drainages and highways from factories, clinics and treatment plants of domestic waste water, especially in developing countries, is the main source of antibiotic pollution of surface water which causes a major public health problem $(10,11)$. Presence of antibiotics in trace amount aids in selecting and establishing antibiotic resistance in microbes for their long time exposure in such environment (12). Furthermore, when such selective pressure leads to the persistence and spread of resistant genes, natural environments become repositories of resistant bacteria as well as resistance genes (13). Considering the facts, present study endeavored to estimate the presence of bacterial contaminants in different biodegradable domestic waste samples. Drug susceptibility pattern of the isolates was determined as well. 


\section{MATERIALS AMD METHODS}

Study period and sampling. The study was carried out at the Microbiology Laboratory, Stamford University Bangladesh from October 2018 to December 2018. Six different domestic waste samples including three kitchen waste samples and one sample each of home dust, dustbin waste and liquid waste were randomly collected in sterile PET bottle or jar and transported to the laboratory at the earliest convenient. For the isolation and enumeration of pathogenic bacteria, $10 \mathrm{~g}$ or $\mathrm{ml}$ of each sample was homogenized in $90 \mathrm{ml}$ normal saline and diluted to $10^{-6}$ according to the standard guidelines (14-19).

Isolation and identification of bacteria

Estimation of total viable bacteria, Escherichia coli, Klebsiella spp. Staphylococcus spp. and Bacillus spp. From the dilutions $10^{-4}$ and $10^{-6}, 0$. $\mathrm{ml}$ of each sample was spread onto the nutrient agar (NA) media for the enumeration of total viable bacteria. Likewise, $0.1 \mathrm{ml}$ of each sample from the dilutions $10^{-2}$ and $10^{-4}$ were introduced onto MacConkey agar, Mannito Salt agar (MSA), Starch agar and Cetrimide agar for the isolation of coliforms (Escherichia coli and Klebsiella spp.), Staphylococcus spp., Bacillus spp. and Pseudomonas spp., consecutively. All plates were then incubated at $37^{\circ} \mathrm{C}$ for $24 \mathrm{~h}(15-21)$.

Isolation of Salmonella spp., Shigella spp. and Vibrio spp. By estimating the possible presence of viable but non-culturable (VBNC) cells $(19,21-25)$, $10 \mathrm{ml}$ of sample was inoculated into $90 \mathrm{ml}$ of Selenite Cysteine broth (SCB) and Alkaline Peptone Water (APW) to enrich Salmonella, Shigella, and Vibrio spp., respectively and incubated at $37^{\circ} \mathrm{C}$ for $6 \mathrm{~h}$. The enriched samples were diluted to $10^{-4}$ and then $0.1 \mathrm{ml}$ from $10^{-2}$ and $10^{-4}$ dilutions were spread onto Salmonella-Shigella (SS) agar and Thiosulfate Citrate Bile salt Sucrose (TCBS) agar to isolate Salmonella spp. and Shigella spp., and Vibrio spp. consecutively. Plates were incubated at $37^{\circ} \mathrm{C}$ for $48 \mathrm{~h}$ for the detection of typical characteristic colonies.

Antibiotic susceptibility test of the isolates. The disc diffusion method was used to examine the antibiotic susceptibility of the isolated bacteria (either sensitive or resistance) on Mueller-Hinton agar (MHA) (Difco, Detroit, MI) (18, 20, 21, 26-28). The commercial antibiotic discs employed in this experiment were: amoxicillin (AMX, $30 \mu \mathrm{g}$ ), amikacin (AK, $10 \mu \mathrm{g}$ ), meropenem (MEM, $10 \mu \mathrm{g}$ ), azithromycin (AZM, $30 \mu \mathrm{g}$ ), ciprofloxacin (CIP $5 \mu \mathrm{g}$ ), cefixime (CFM, $5 \mu \mathrm{g}$ ), cefuroxime (CXM, $30 \mu \mathrm{g}$ ), ceftriaxone (CTR $30 \mu \mathrm{g}$ ), trimethoprime-sulfamethoxazole (COT, $25 \mu \mathrm{g}$ ) and Ceftazidime/Clavulanic acid (CAC, 30/10 $\mu \mathrm{g}$ ). After bacterial lawn and placing antibiotic discs on MHA, the plates were incubated at $37^{\circ} \mathrm{C}$ for $8 \mathrm{~h}$. Zone of inhibition was measured in $\mathrm{mm}$ for respective bacterial isolates.

\section{RESULTS \& DISCUSSION}

Determination of the presence of bacterial isolates in the tested domestic waste samples. In present study, all the samples were found to contain huge load of viable bacteria on average $10^{8} \mathrm{cfu} / \mathrm{ml}$ or $\mathrm{g}$ (Table 3.1 ) as found previously from different environmental samples $(18,22,26,29)$. Atalia et al. (2015) reported a large numbers of microorganisms in household solid wastes in their study on microbial biodiversity in such samples (30). Higher microbial load in household wastes was found by other researchers (31) using
DNA microarray and other molecular techniques. Several studies also reported different pathogenic bacteria in the different domestic waste samples (3134). As found in previous investigations, specific bacterial isolates were recovered in significant quantities from all the samples in present study (Table 1). Bacillus spp. was predominant and found in all types of samples in an average of $10^{7} \mathrm{cfu} / \mathrm{ml}$ or $\mathrm{g}$. Vibrio spp. was also present in almost all samples excluding the liquid waste. Whereas, Pseudomonas spp. was found in four samples (Table 1). Klebsiella spp., E. coli and fecal coliform each were present in three samples. Two samples contained Staphylococcus spp. and Salmonella spp. All the samples were devoid of Shigella spp. (Table 1). The higher microbial load found in the household waste samples was possibly due to the presence of accessible nutrients (30).

Antibiotic susceptibility pattern of the isolates. In current study, all tested isolates were found to be multidrug resistant (resistant against at least two or more drugs) (Table 2). All the isolates were found to be resistant against cefuroxime and amoxicillin. On the other hand, meropenem, ceftriaxone and amikacin sensitivity were observed for all isolates. Majority of the isolates were sensitive to azithromycin. Isolates of Klebsiella spp. and Bacillus spp. showed resistance against ceftazidime/clavulanic acid, ciprofloxacin and cefixime. Ceftazidime/clavulanic acid and cefixime resistance were exhibited by Staphylococcus spp. Salmonella spp. and Vibrio spp. were found to be resistant against trimethoprime/sulfamethoxazole (Table 2). Similar to the present study, Adieze et al. (2015) found multidrug resistant bacteria in the domestic and hospital waste samples (35). In India, Pandey et al. (2011) found multidrug resistant bacteria in waste water samples (36). Kummerer (2004) also reported bacterial antibiotic resistance in different types of waste samples (37). Unregulated disposal of domestic waste containing organic substances, together with toxic chemicals inclusive of antibiotics and pathogenic bacteria, can play a major role in the accumulation of bacterial drug resistance $(4,38-40)$.

Table 1. Isolation and quantification of pathogenic bacteria from different domestic waste samples

\begin{tabular}{|c|c|c|c|c|c|c|c|c|c|}
\hline $\begin{array}{c}\text { Domestic } \\
\text { waste Samples }\end{array}$ & $\begin{array}{c}\text { TVB } \\
\text { (cfu/g or } \\
\text { ml) }\end{array}$ & $\begin{array}{l}\text { Staphylococcus } \\
\text { spp. } \\
\text { (cfu/g or ml) }\end{array}$ & $\begin{array}{c}\text { Klebsiella } \\
\text { spp. } \\
\text { (cfu/g or } \\
\text { ml) }\end{array}$ & $\begin{array}{c}\text { E. coli } \\
\text { (cfu/g } \\
\text { or ml) }\end{array}$ & $\begin{array}{c}\text { TFC } \\
(\mathrm{cfu} / \mathrm{g} \\
\text { or ml) }\end{array}$ & $\begin{array}{c}\text { Bacillus } \\
\text { spp. } \\
\text { (cfu/g } \\
\text { or ml) }\end{array}$ & $\begin{array}{l}\text { Pseudomonas } \\
\text { spp. } \\
\text { (cfu/g or ml) }\end{array}$ & $\begin{array}{c}\text { *Salmonella } \\
\text { spp. }\end{array}$ & $\begin{array}{l}\text { *Vibrio } \\
\text { spp. }\end{array}$ \\
\hline Kitchen waste 1 & $4.3 \times 10^{8}$ & 0 & $5.0 \times 10^{6}$ & 0 & 0 & $4.8 \times 10^{7}$ & $9.5 \times 10^{6}$ & + & + \\
\hline Kitchen waste 2 & $1.6 \times 10^{8}$ & 0 & 0 & $6.0 \times 10^{6}$ & $5.0 \times 10^{6}$ & $4.0 \times 10^{7}$ & 0 & - & + \\
\hline Kitchen waste 3 & $2.5 \times 10^{8}$ & $4.0 \times 10^{5}$ & 0 & 0 & 0 & $7.2 \times 10^{7}$ & $4.0 \times 10^{5}$ & - & + \\
\hline Home dust & $5.4 \times 10^{8}$ & $4.5 \times 10^{6}$ & $1.2 \times 10^{6}$ & 0 & $3.6 \times 10^{6}$ & $4.1 \times 10^{7}$ & 0 & + & + \\
\hline Dustbin waste & $5.5 \times 10^{8}$ & 0 & $2.0 \times 10^{7}$ & $2.2 \times 10^{6}$ & $4.0 \times 10^{6}$ & $5.0 \times 10^{7}$ & $1.6 \times 10^{6}$ & - & + \\
\hline Liquid waste & $1.0 \times 10^{8}$ & 0 & 0 & $3.3 \times 10^{6}$ & 0 & $2.0 \times 10^{7}$ & $7.6 \times 10^{6}$ & - & - \\
\hline
\end{tabular}

TVB = Total viable bacteria TFC $=$ Total fecal coliform; $+=$ Present $;-=$ Absent

*Presence or absence of bacteria after enrichment

Shigella spp. were absent in all samples. 
Table 2. Antibiotics susceptibility pattern of the isolates from the domestic waste samples

\begin{tabular}{lcccccccccc}
\hline \multirow{2}{*}{ Isolates (n) } & \multicolumn{10}{c}{ Antibiotics (\% resistant isolates) } \\
\cline { 2 - 10 } & CAC & MEM & COT & CIP & AZM & CFM & CTR & CXM & AMX & AK \\
\hline Staphylococcus spp. (2) & 100 & 0 & 0 & 50 & 0 & 100 & 0 & 100 & 100 & 0 \\
Salmonella spp. (2) & 0 & 0 & 100 & 50 & 0 & 100 & 0 & 100 & 100 & 0 \\
Pseudomonas spp. (4) & 25 & 0 & 25 & 0 & 0 & 50 & 0 & 100 & 100 & 0 \\
Vibrio spp. (5) & 20 & 0 & 80 & 40 & 0 & 40 & 0 & 100 & 100 & 0 \\
Klebsiella spp. (3) & 100 & 0 & 0 & 100 & 33.3 & 100 & 0 & 100 & 100 & 0 \\
Bacillus spp. (6) & 100 & 0 & 33.3 & 100 & 0 & 100 & 0 & 100 & 100 & 0 \\
E. coli (3) & 25 & 0 & 0 & 33.3 & 33.3 & 33.3 & 0 & 100 & 100 & 0 \\
\hline
\end{tabular}

$\mathrm{n}=$ number of isolates

$\mathrm{CAC}=$ Ceftazidime/Clavulanic acid $(30 / 10 \mu \mathrm{g}) ; \mathrm{MEM}=$ Meropenem $(10 \mu \mathrm{g}) ; \mathrm{COT}=$ Trimethoprime/sulfamethoxazole $(25 \mu \mathrm{g}) ; \mathrm{CIP}=$ Ciprofloxacin $(5 \mu \mathrm{g}) ; \mathrm{AZM}=$ Azithromycin $(30 \mu \mathrm{g}) ; \mathrm{CFM}=$ Cefixime $(5 \mu \mathrm{g})$; CTR = Ceftriaxone $(30 \mu \mathrm{g}) ; \mathrm{CXM}=$ Cefuroxime $(30 \mu \mathrm{g})$, $\mathrm{AMX}=$ Amoxicillin $(30 \mu \mathrm{g}) ; \mathrm{AK}=\operatorname{Amikacin}(10 \mu \mathrm{g})$.

\section{CONCLUSION}

The findings of the current study revealed that all the samples contained a huge number of bacterial isolates. Multidrug resistance was found in all the isolates of different bacterial species. Presence of pathogenic bacteria with antibiotic resistance traits portrayed serious public health threats. Antibiotic resistant pathogens may extend the hazards related to the poorly managed wastes. Unplanned dumping of untreated domestic liquid and solid wastes into municipal drain and dump sites may continually accelerate this problem. Proper management of household waste should therefore be ensured. Thus, this study urges the need for a national policy on household waste management.

\section{ACKNOWLEDGEMENT}

Authors would like to thank Stamford University Bangladesh for the financial and technical supports.

\section{REFERENCES}

1. Zacarias-Farah A and Geyer-Allely E. 2003. Household consumption patterns in OECD countries: trends and figures. J. Clean Prod. 11:819827.

2. Slack RJ, Gronow JR and Voulvoulis N. 2004. Hazardous components of household waste. Crit. Rev. Environ. Sci. Technol. 34:419-445.

3. Jilani S. 2007. Municipal solid waste composting and its assessment for reuse in plant production. Pak. J. Botany. 39:271

4. Wang Q, Yamabe K, Narita J, Morishita M, Ohsumi Y, Kusano K et al. 2001. Suppression of growth of putrefactive and food poisoning bacteria by lactic acid fermentation of kitchen waste. Proc. Biochem. 37:351-357.

5. Luostarinen S and Rintala J. 2007. Anaerobic on-site treatment of kitchen waste in combination with black water in UASB-septic tanks at low temperatures. Biores. Technol. 98:1734-1740.

6. Fu H, Zeng G, Zhong H, Yuan X, Wang W, Huang G et al. 2007. Effects of rhamnolipid on degradation of granular organic substrate from kitchen waste by a Pseudomonas aeruginosa strain. Colloids Surf. B. 58:91-97.

7. Bronswijk JEMHvan. 1981. House dust biology: for allergists, acarologists, and mycologists / by Johanna E.M.H. van Bronswijk J Bronswijk ; World-wide distributor, NIB Publishers Zoelmond : Zeist, The Netherlands.

8. Hyvlrinen A, Reponen T, Husman T, Ruuskanen J and Nevalainen A 1993. Characterizing mold problem buildings concentrations and flora of viable fungi. Indoor Air 3:337-343.

9. Miller JD, Laflamme AM, Sobol Y, Lafontaine P and Greenhalgh R. 1988. Fungi and fungal products in some Canadian houses. Int. Biodetn. 24:103-120.

10. Alagoz BAZ and Kocasoy G. 2007. Treatment and disposal alternatives
Istanbul, Turkey. Waste Man Res. 25:83-89.

11. Abah SO and Ohimain EI. 2010. Assessment of dumpsite rehabilitation potential using the integrated risk based approach: A case study of Eneka, Nigeria. World Appl. Sci. J. 4:436-442.

12. Kolpin DW, Furlong ET, Meyer MT, Turman EM, Zaugg SD, Barber LB, et al. 2002. Pharmaceuticals, hormones, and other organic wastewater contaminants in U.S. streams, 1999-2000: A national reconnaissance. Environ Sci. Technol. 36:1202-1211.

13. Tacão M, Correia A and Henriques I. 2012. Resistance to broadspectrum antibiotics in aquatic systems: Anthropogenic activities modulate the sissemination of blaCTX-M-like genes. Appl. Environ. Microbiol. 78:4134-4140.

14. Cappuccino JG and Sherman N. 1996. Microbiology - A laboratory manual. The Benjamin/Cummings Publishing Co., Inc. Menlo Park, California

15. Acharjee M, Jahan F, Rahman F and Noor R. 2013. Bacterial proliferation in municipal water supplied in mirpur locality of Dhaka city, Bangladesh. Clean Soil Air Water. 42:1-8.

16. Sharmin M, Nur IT, Acharjee M, Munshi SK and Noor R. 2014. Microbiological profiling and the demonstration of in vitro anti-bacterial traits of the major oral herbal medicines used in Dhaka Metropolis. SpringerPlus. 3:739.

17. Jahan N, Noor R. and Munshi SK. 2018. Microbiological analysis and determination of antimicrobial traits of green banana (Musa spp.) and papaya (Carica papaya). Stam. J. Microbiol. 8:41-45.

18. Munshi SK, Haque T and Noor R. 2018. Influence of multi-species biofilm formed in vitro from different environmental samples on the drug-resistance traits of resident bacteria. Bang. J. Microbiol. 35:108114.

19. Chakraborty M, Afrin T and Munshi SK. 2019. Microbiological quality and antimicrobial potential of extracts of different spices. Food Res. 4:375-379.

20. Akter M, Sultana S and Munshi SK. 2019. Microbiological quality assessment of ready-to-eat fried chicken and chicken soup samples sold in Dhaka Metropolis, Bangladesh. Sumer. J. Biotechnol. 2:48-54.

21. Ahmed T, Urmi NJ, Munna MS, Das KK, Acharjee M, Rahman MM, et al. 2014. Assessment of microbiological proliferation and in vitro demonstration of the antimicrobial activity of the commonly available salad vegetables within Dhaka metropolis, Bangladesh. Am. J. Agri. Forestr. 2:55-60.

22. Munshi SK, Roy J and Noor R. 2018. Microbiological Investigation and determination of the antimicrobial potential of cow dung samples. Stam. J. Microbiol. 8:34-37.

23. Colwell RR. 2000. Non-culturable microorganisms in the environment. American Society of Microbiology, Washington DC, USA.

24. Rahman F and Noor R. 2012. Prevalence of pathogenic bacteria in common salad vegetables of Dhaka Metropolis. Bang. J. Bot. 41:159162.

25. Oliver JD. 2005. The viable but nonculturable state in bacteria. J. Microbiol. 43:93-100.

26. Munshi SK, Rahman MM and Noor R. 2012. Detection of virulence potential of diarrheagenic Escherichia coli isolated from surface water of rivers surrounding Dhaka City. J. Bang. Acad. Sci. 36:109-122.

27. Bauer AW, Kirby WMM, Sherris JC and Tierch M. 1968. Antibiotic susceptibility testing by a standardized single disc method. American J. Clin. Pathol. 45:493-496.

28. Ferraro MJ, Craig WA and Dudley MN. 2001. Performance standards for antimicrobial susceptibility testing. NCCLS, Pennsylvania, USA.

29. Acharjee M, Rahman F, Beauty SA, Feroz F, Rahman MM and Noor R. 
2011. Microbiological study on supply water and treated water in Dhaka city. S. J. Microbial. 1:42-45

30. Atalia KR, Buha DM, Joshi JJ and Shah NK. 2015. Microbia biodiversity of municipal solid waste of Ahmedabad. J. Mater. Environ. Sci. 6:1914-1923.

31. Sundberg C, Franke-Whittle IH, Kauppi S, Yu D, Romantschuk M Insam H, et al. 2011. Characterisation of source-separated household waste intended for composting. Biores. Technol. 102:2859-2867.

32. Ryckeboer J, Mergaert J, Vaes K, Klammer S, De Clercq D, Insam I, et al. 2003. A survey of bacteria and fungi occurring during composting and selfheating processes. Ann. Microbiol. 53:349-410.

33. Cayuela ML, Mondini C, Insam H, Sinicco T and Franke-Whittle I 2009. Plant and animal wastes composting: effects of the N source on process performance. Biores. Technol. 100:3097-3106.

34. Danon M, Franke-Whittle IH, Insam H, Chen Y and Hadar Y. 2008 Molecular analysis of bacterial community succession during prolonged compost curing. Fems. Microbiol. Ecol. 65:133-144.

35. Adieze IE, Nnadi C, Braide W, Azubuike C and Nduka I. 2015. Antibiotic resistance pattern of bacterial isolates of liquid wastes and waste dump soils of hospitals in Owerri, Nigeria. Niger. J. Microbiol. 29:3002-3011.

36. Pandey A, Afsheen, Ara F and Tiwari SK. 2011. Isolation and characterization of multi drug resistance cultures from waste water. J. Pharm. Biomed. Sci. 13:1-7.

37. Ku"mmerer K. 2004. Resistance in the environment. J. Antimicrob. Chem. 54:311-320.

38. Choudhury R, Panda S and Singh DV. 2012. Emergence and dissemination of antibiotic resistance: A global problem. Indian J. Med. Microbiol. 30:384-390.

39. Schwartz T, Kohnen W, Jansen B and Obst U. 2003. Detection of antibiotic-resistant bacteria and their resistance genes in wastewater, surface water and drinking water biofilms. FEMS Microbiol. Ecol. 43:325-335.

40. Davies $\mathrm{J}$ and Davies D. 2010. Origins and evolution of antibiotic resistance. Microbiol. Mol. Biol. Rev. 74:417-433. 